\title{
Copyright protection of street art and graffiti in Greece: intellectual property and personal property in conflict?
}

Book or Report Section

Accepted Version

Karapapa, S. (2019) Copyright protection of street art and graffiti in Greece: intellectual property and personal property in conflict? In: Bonadio, E. (ed.) The Cambridge Handbook of Copyright in Street Art and Graffiti. Cambridge University Press, pp. 239-254. ISBN 9781108563581 doi: https://doi.org/10.1017/9781108563581.016 Available at http://centaur.reading.ac.uk/77704/

It is advisable to refer to the publisher's version if you intend to cite from the work. See Guidance on citing.

To link to this article DOI: http://dx.doi.org/10.1017/9781108563581.016

Publisher: Cambridge University Press

All outputs in CentAUR are protected by Intellectual Property Rights law, including copyright law. Copyright and IPR is retained by the creators or other 
copyright holders. Terms and conditions for use of this material are defined in the End User Agreement.

\section{www.reading.ac.uk/centaur}

\section{CentAUR}

Central Archive at the University of Reading

Reading's research outputs online 


\section{Copyright protection of street art and graffiti in Greece: intellectual property and personal property in conflict?}

Professor Stavroula Karapapa, University of Reading

\section{Introduction}

On 11 November 2014, the Guardian paid tribute to the Greek street art that has spurred in light of hardships and unemployment owing to the Greek economic crisis, referring to Athens as 'a new Mecca for street artists'. ${ }^{1}$ Hosting images of graffiti featuring on walls of the Greek capital, the Guardian remarked that street murals are complex and they vary in style, expressing political insights, drawing inspiration from financial constraints or offering feelings of hope and aspiration. Greece, and mostly Athens, is in the middle of a graffiti epidemic.

Perhaps the more controversial graffiti of recent years was the one on the walls of the National and Technical University of Athens (NTUA) (Ethniko Metsovio Polytechneio). ${ }^{3}$ Just within a night, the historical building of the University was transformed into the host one of the most emblematic graffiti works ever made in Greece. Emerging as waves in a turbulent sea—or, to some, as abstract figures — the brushstrokes were as intense as they were shocking. It was not only the unparalleled speed involved in the creation of this graffiti that caught the public by surprise, the

\footnotetext{
${ }^{1}$ Milos Bicanski, Contemporary Graffiti Art on the Walls of Athens - In Pictures, THE GUARDIAN, (Nov. 11, 2014, 09.30 GMT), https://www.theguardian.com/world/gallery/2014/nov/11/contemporarygraffiti-art-on-the-walls-of-athens-in-pictures; There is a facebook page hosting images of the graffiti art in Athens: https://www.facebook.com/GraffitilnAthens/; Some important street artists are listed

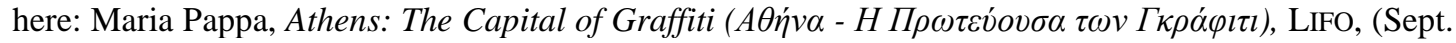
18, 2013), http://www.lifo.gr/mag/features/3971\#comment.

${ }^{3}$ Eleni N. Stamatiou, Urban Web, Spatial Transformation and Dubious Artistic Interventions: The

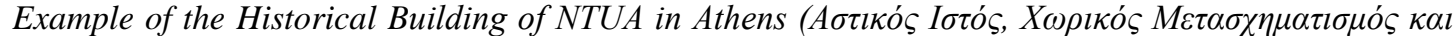

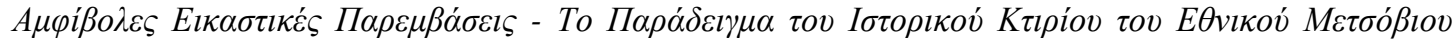

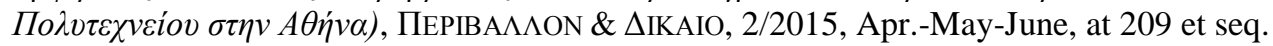


graffiti was also impressive in its volume, covering all surfaces-walls, windows and posters on walls — with black and white paint, not spray (Figure 1). Public opinion on the work was divided. ${ }^{4}$ To some, this was art, an extremist, yet rebellious moment of artistic creation, turning NTUA into the 'cover of an artistic novel' ${ }^{5}$ To others, it was an act of vandalism against public property, public education, and the public interest, justifying the urgent intervention of the Public Prosecutor's office to investigate and assess whether a special form of damage on a public building of historical importance could be established. ${ }^{6}$

Controversy accelerated when the Municipality of Athens in collaboration with the Senate of the University decided to erase the graffiti. Soon after the workers started washing off the paint, there was an announcement of a rally ${ }^{7}$ and a group of citizens formed a human chain around the building to protest. ${ }^{8}$ It is doubtful whether the same level of controversy would arise by reference to graffiti in other public places and indeed, when various other public buildings and sculptures of the University of Athens were painted with slogans and black paint a few days after the

\footnotetext{
${ }^{4}$ See eg Paraskevi Vonatsou, The NTUA Graffiti: Art or Vandalism? - What do Citizens say?

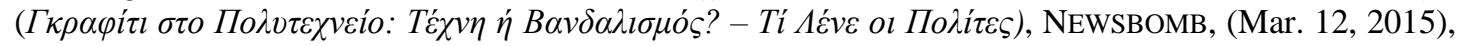
http://www.newsbomb.gr/ellada/news/story/565672/gkrafiti-sto-polytexneio-texni-i-vandalismos-tilene-oi-polites; The Lifo Team, The Huge Graffiti that Covered the Politecnic Divides Public Opinion

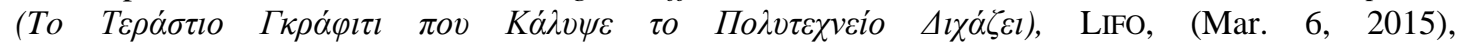
http://www.lifo.gr/now/culture/62078 (where a poll was enacted to ask readers whether they agree with graffiti interventions such as the one at NTUA and an overwhelming $40.77 \%$ voted against it and about $36.52 \%$ said they agree with such interventions under certain conditions); Aris Dimokidis, Graffiti and

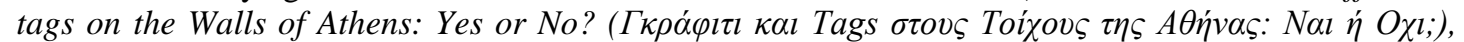
LIFO, (Apr. 6, 2016), http://www.lifo.gr/articles/mikropragmata/96245 (where a poll about public opinion on whether graffiti and tags should remain in Athens revealed that $51 \%$ voted no, $27 \%$ opined that it should be graffiti only to remain and $0 \%$ was in favour of the maintenance of tags).

${ }^{5}$ Alexandros Papadopoulos, The NTUA Graffiti is more Classic than a Neo-classic Building: Science

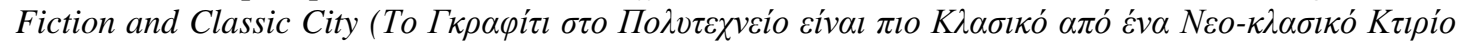

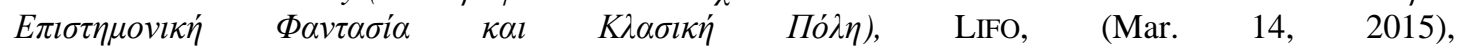
http://www.lifo.gr/team/athens/56100.

${ }^{6}$ Criminal Law Code, Art. 382(4) ; Urgent Investigation from the Prosecutor's Office on the NTUA

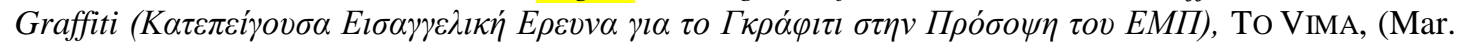
9, 2015), http://www.tovima.gr/society/article/?aid=683798.

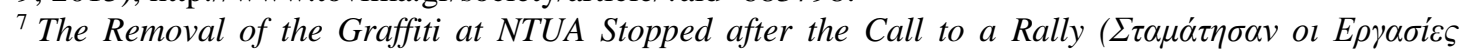

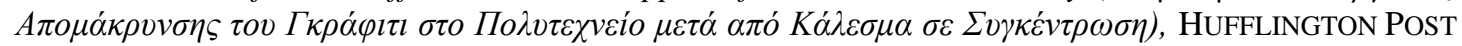
GREECE, (Mar. 16, 2015), http://www.huffingtonpost.gr/2015/03/16/koinwnia-stamathsangrafiti_n_6877164.html.

${ }^{8}$ See e.g. https://www.youtube.com/watch?v=e2KMriXMP0I.
} 
NTUA incident, the public did not equally revolt when the Municipality of Athens decided to wash those graffiti off.

Was it art or was it vandalism? ${ }^{9}$ What made the NTUA graffiti particularly controversial goes beyond this dilemma, due to the historical and political status of the building. ${ }^{10}$ Historically, NTUA has become a symbol of freedom and resistance: in November 1973, the then-called Athens Polytechnic was the epicentre of the events that escalated to an open revolt against the military junta of 1967-1974, with a tank notoriously crashing through the gates of the Polytechnic. The $17^{\text {th }}$ of November is currently observed as a holiday for all educational establishments in Greece, with commemorative events taking place in all the schools of the country and with deposition of wreaths on the campus of NTUA. Around the same dates every year, however, celebrations are marked with episodes where anarchist groups and other unidentified parties intrude the memorial procession, initiating incidents against public or private property, the police, and the special forces. Seen in this light, the NTUA graffiti would not raise as much controversy as a form of art in isolation from its underlying political connotation.

Graffiti art, and its possible destruction by the owners of the material support, brings to light the conflict between two property rights: intellectual property rights on the work and property rights on the material support. ${ }^{11}$ Indeed, whereas copyright may subsist in a graffiti — and in this light the graffiti would qualify as a work of artthe owner of the wall or other surface remains entitled to wash it off. The question

\footnotetext{
${ }^{9}$ Various opinions expressed here: Olga Klontza \& Eleni Konstantatou, If they Could, Would they have

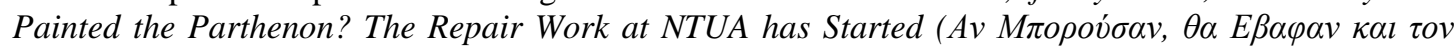

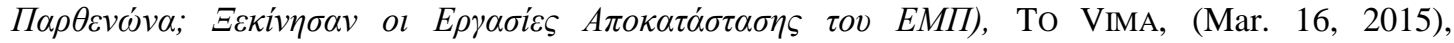
http://www.tovima.gr/society/article/?aid=685703.

${ }^{10}$ Eleni N. Stamatiou, Urban Web, Spatial Transformation and Dubious Artistic Interventions: The

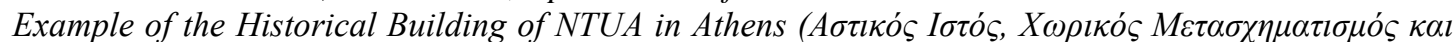

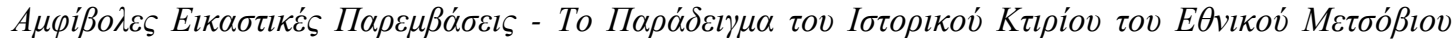

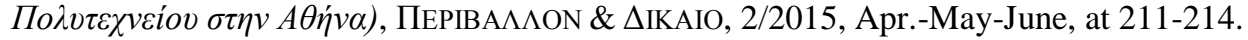

${ }^{11}$ It also brings about the conflict between freedom of speech and artistic expression versus acts of vandalism on urban environment and public property.
} 
strikes at the heart of a critical legal problem, namely the extent to which the owner of an artistic work is entitled to destroy it, which goes beyond the specific issues surrounding graffiti work. In this aspect, the question has both positivist and normative implications. Is the destruction of artworks copyright infringement and in particular a violation of the integrity right? Does copyright law in Greece (and also possibly elsewhere in the EU) address instances of such conflict? To what extent is the available legal framework satisfactory and how should the conflict between intellectual property rights and property rights be regulated to reach an appropriate balance between the interests at stake?

\section{[INSERT FIGURE 1 HERE]}

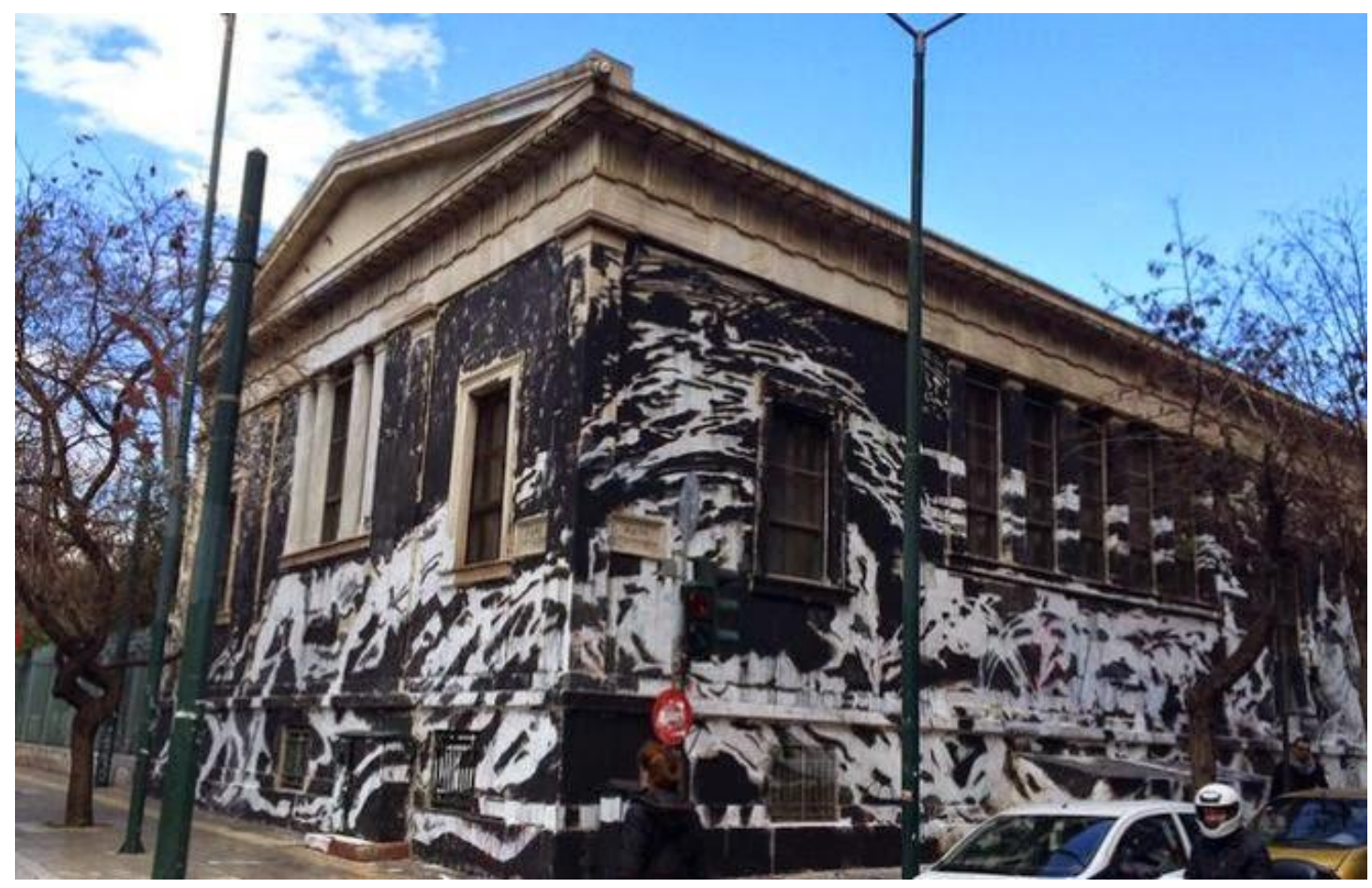

Figure 1: The NTUA graffiti. Image copied from: http://www.inewsgr.com/135/aftoikalypsan-me-gkrafiti-to-polytechneio.htm

\section{Street art as copyrightable subject matter}


Street art is an amorphous, yet encompassing term covering various types of visual art in public locations. ${ }^{12}$ An important technical and legal distinction in works of street art is one between graffiti and murals. Graffiti commonly refers to spray-painting without the wall owner's permission, covering mostly lettering styles. Murals are brush-painted images and, often, figurative demonstrations going beyond lettering and they are often (yet not always) commissioned and funded.

Originating from the Italian word graffiato ('scratched'), the term graffito (singular) was originally used in art history and archaeology by reference to carvings on the remnants of ancient monuments. Often these carvings featured the name of the engraver, the year of the engraving, or a short message, and they would be equivalent to what today's graffiti refers to as 'tags'. The term further goes back to the Greek word $\gamma \rho \alpha \dot{\varphi} \varphi \varepsilon \imath v$, which means 'to write'. In 1976, Mabel Lang from the American School of Classical Studies catalogued in Athens more than 800 examples of graffiti from ancient times, dating from the 8 th century $\mathrm{BC}$ to the late 6th century AD. Modern graffiti has evolved by including not just tags, letters or short messages but also forms of street artistic expression comprising large pieces of artistic works.

In principle, works of street art can qualify for copyright protection as literary or artistic works under the Greek copyright subject to the conditions outlined in the Greek Copyright Act, namely Law 2121/93. ${ }^{13}$ Some forms of street art are more likely to attract protection than others. The statute offers a broad, yet indicative definition of what qualifies as protectable subject-matter. According to Article 2(1):

The term 'work' shall designate any original intellectual literary, artistic or scientific creation, expressed in any form, notably written or oral texts,

\footnotetext{
${ }^{12}$ Eric Wooters Yip, What Is Street Art? Vandalism, Graffiti or Public Art - Part I ART RADAR, (Jan. 21, 2010), http://perma.cc/ETH6-F785; Peter N. Salib, The Law of Banksy: Who Owns Street Art?, 82 THE UNIVERSITY OF CHICAGO LAW REVIEW, 2293, at 2295 et seq (2015).

${ }^{13}$ Law 2121/1993 on Copyright, Related Rights and Cultural Matters (1993), available in English at http://www.wipo.int/wipolex/en/details.jsp?id=1790.
} 
musical compositions with or without words, theatrical works accompanied or unaccompanied by music, choreographies and pantomimes, audio-visual works, works of fine art, including drawings, works of painting and sculpture, engravings and lithographs, works of architecture, photographs, works of applied art, illustrations, maps, three dimensional works relative to geography, topography, architecture or science.

The three main conditions arising from this provision are that the work should be an intellectual creation, it should be the expression of an idea, and it should be original. Once these conditions are met, the work is protected irrespectively from its aesthetic quality or artistic merit, its legality or lack thereof, and regardless of the fact that the work may receive protection under other legal provisions too. ${ }^{14}$ This is a unique feature of the Greek copyright system that - unlike other jurisdictions where illegality of a work will be a ban to copyright protection - it is immaterial whether the work is the product of illegal activity, as is often the case with unauthorised graffiti.

\section{A. A work}

The list of protectable subject-matter offered in Article 2(1) is only indicative and does not preclude from protection intellectual creations that are not expressly mentioned. This is even more so in light of the jurisprudence of the Court of Justice of the European Union that has expanded the breadth of protectable subject-matter by according protection to any and every work that qualifies as the 'author's own intellectual creation'. ${ }^{15}$ Greek copyright does not set a requirement of minimum length, ${ }^{16}$ meaning that, in the context of graffiti, even tags or bubble-style letters

\footnotetext{
${ }^{14}$ Law 2121/1993, Art. 2(4).

${ }^{15}$ Infopaq International A/S v Danske Dagblades Forening, Case C-5/08 [2009] ECR I-6569, at 33-37; Bezpečnostní softwarová asociace-Svaz softwarové ochrany v Ministerstvo kultury, Case C-393/09 [2010] ECR I-13971, at 45-46.

16 Georgios Koumantos, Intellectual Property (ПneymatiK'H I $\Delta$ IOKThzia) (Athens: Ant. N. Sakkoulas $1995,6^{\text {th }}$ ed.), at 94,95 .
} 
could in principle receive protection. Indeed, various forms of street art are likely to qualify as protectable subject-matter, either as literary works (slogans, tags) or artistic works (graffiti, murals, 'throw ups', i.e. bubble-style letters and graffiti letters etc).

\section{B. Protecting the expression rather than idea}

Same as in international law, ${ }^{17}$ Greek copyright law makes a distinction between protectable expression and unprotectable ideas, facts, and information. This is inferred from Article 2(1) of Law 2121/93, which affords protection to the 'form' of the work as the protected element thereof. The purpose of the provision is to ensure free access of authors to ideas in order to create new works and to ensure exploitation of that particular form only, so that the idea remains res communis for all to use. There is rich case law in Greece confirming the idea/expression dichotomy ${ }^{19}$ and drawing a distinction between two forms of the work: the internal and the external. The latter form refers to the exact expression of the work and the former to the underlying context and framework (e.g. plot or logical sequence of arguments), which is often what is taken in derivative works and there is hence a possible copyright violation unless authorisation is given. It is not difficult to see how the idea/expression dichotomy manifests itself by reference to works of street art. With regards to works where only a specific expression is possible or where the function of the intellectual creation allows one and only form of the work, theory accepts that the form and the content, i.e. the expression and the idea, may collide. This may be argued by reference to simple shapes of letters. In such a case, protection is unlikely to subsist in the work

\footnotetext{
${ }^{17}$ This stems from Article 9(2) of the TRIPS Agreement, which clearly indicates that copyright protects creative expressions and not ideas, processes, methods of operation and mathematical concepts (N. 2290/1995, ФEK 28/A/1995). This follows an almost identical provision included in Article 2 of the WIPO Copyright Treaty (N. 3184/2003, ФEK 228/A/26-09-2003).

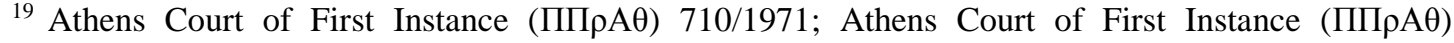

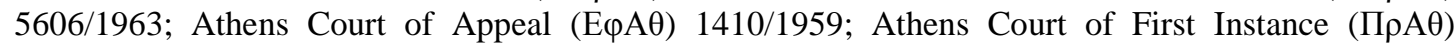
$5480 / 1935$.
} 
either because originality cannot be inferred or because copyright refuses to afford protection to the idea alone. $^{20}$

\section{Originality}

Although originality is a requirement of protection according to Article 2(1) of Law $2121 / 93$, it is not statutorily defined and its concept has developed in theory ${ }^{21}$ and case-law. The traditional meaning of originality under Greek copyright aligns with the threshold of originality required in continental Europe, according to which originality can be seen as the imprint of the author's personality on the work. In this light, Greek copyright did not have to depart significantly from its traditional interpretation of originality in order to accommodate the rulings of the Court of Justice that have elaborated on the concept of originality under EU copyright. ${ }^{22}$ In Infopaq, a case involving the storing and subsequent printing out of 11-word extracts from daily newspapers the Court of Justice held that 'copyright ... is liable to apply only in relation to a subject-matter which is original in the sense that it is its author's own intellectual creation'. ${ }^{23}$ In Greece, originality is seen as the result of the personal contribution of the author, on the basis of which the work presents some uniqueness that distinguishes it from intellectual products of every day life. ${ }^{24}$

There are two approaches on the meaning of uniqueness in this context. The first requires statistical uniqueness of the work at issue, meaning that a work is original when no other author-under the same conditions and objectives-would

\footnotetext{
${ }^{20}$ Athens Court of Appeal (E $\left.\varphi A \theta\right)$ 2969/2012; Larisa Court of Appeal (E $\left.\varphi \Lambda \alpha \rho\right)$ 82/2010; Athens Court

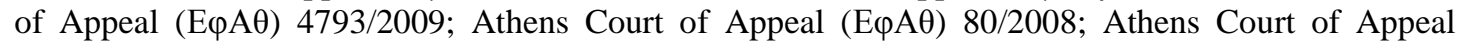
(Е $\varphi A \theta)$ 2932/2006.

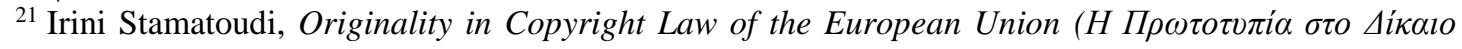

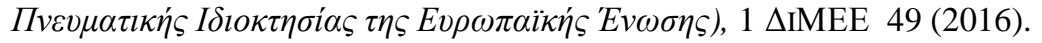

${ }^{22}$ Infopaq International A/S v Danske Dagblades Forening, C-5/08 [2009] ECR I-6569; Eva-Maria Painer v Standard VerlagsGmbH and Others, C-145/10 [2012] ECDR 6; Football Dataco Ltd and others v. Yahoo! UK Ltd and others, Case C-604/10 [2010] EWCA Civ 1380.

${ }^{23}$ Infopaq International A/S v Danske Dagblades Forening Case C-5/08 [2009] ECR I-6569, at [37]

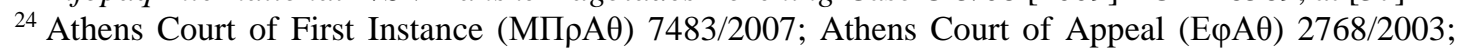

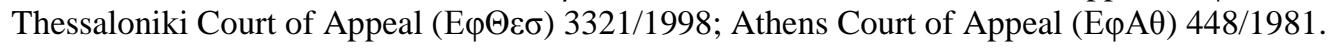


create the same work. ${ }^{25}$ The second approach requires a minimum level of creative height, which can only be inferred once a work is distinct or different from already known works, ${ }^{26}$ or it distinguishes itself from intellectual products of every day life that are ordinary or routinely made. ${ }^{27}$ The concept of creative height is the copyright equivalent of inventive step in patent law. ${ }^{28}$ In most instances, case-law combines both conditions of statistical uniqueness and creative height, defining the protected subject-matter as one that is a perceptible product reflecting the author's personality and being characterised by originality: the work is hence original if it presents some particular expression that is assessed from the perspective of its statistical uniqueness and creative height, taking a distance from what is ordinary and self-evident. ${ }^{29}$

The uniqueness of the work can be identified by reference to one of its aspects, e.g. the topic, its conception, expression or some of its elements, depending on their kind and nature. In order to determine originality, it is not sufficient that the work is not a copy from another work and it is immaterial how much effort, skill or investment has been expended in its creation. What matters is that the work as a whole is statistically unique. The work, hence, is protected as an intellectual objectand not as a material object incorporating a work-in the particular form of expression that its author afforded to it. ${ }^{30}$ Regarding photographs in particular, Greek

\footnotetext{
${ }^{25}$ Athens Court of First Instance (МПрА $)$ 9499/1996.

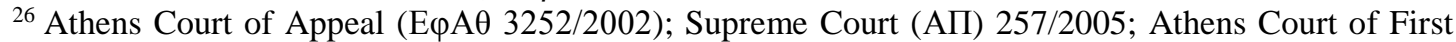

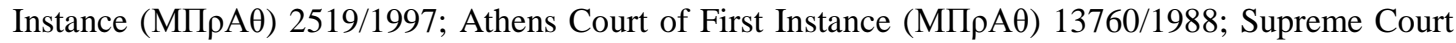
(АП) $525 / 1985$.

${ }^{27}$ Supreme Court (АП) 113/1989; Athens Court of Appeal (Е $\varphi$ A $\left.\theta\right)$ 3403/1988; Athens Court of Appeal $(\mathrm{E} \varphi \mathrm{A} \theta)$ 448/1981.

${ }^{28}$ Athanasios Liakopoulos, Industrial Property (BIOMHXANiKH I $\triangle$ IOKTHEIA) (Athens: P. N. Sakkoulas 2000, 5th ed.) II 2, at [XXX8-11].

${ }_{29}$ Supreme Court, Criminal Chamber $(\mathrm{A} \Pi(\pi \mathrm{ov} v))$ 2330/2007; Athens Court of Appeal $(\mathrm{E} \varphi \mathrm{A} \theta)$ 2768/2003; Athens Court of Appeal (Е $\varphi A \theta$ ) 3252/2002; Athens Court of First Instance (ПП $\rho A \theta$ ) 7518/2000; Supreme Court (АП) 267/1995.

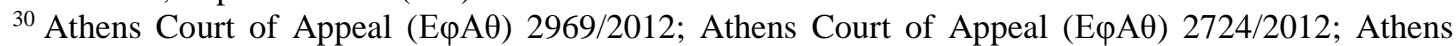

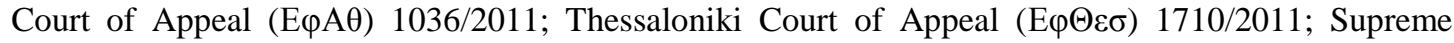
Court (АП) 196/2010; Supreme Court (АП) 537/2010; Supreme Court (АП) 152/2005; MICHAEL-

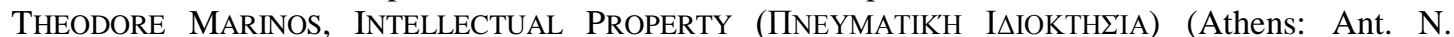
Sakkoulas YEAR, $2^{\text {nd }}$ ed.) at 76-83; DiONYSIA KALLINIKOU, INTELLECTUAL ProPERTY AND
} 
case law limits itself to exploring whether statistical uniqueness exists, creating in this sense a 'presumption' of originality. ${ }^{31}$

Greek courts have found originality in a variety of subject-matter, including a newspaper article resulting from an interview, ${ }^{32}$ a work on mathematics, ${ }^{33}$ a magazine, ${ }^{34}$ a sculpture featuring a marble tomb stone with complicated engravings, ${ }^{35}$ a jewellery design in the shape of a dragonfly, ${ }^{36}$ plaster made table lamps,${ }^{37}$ or the design of a suitcase.$^{38}$ Originality could not subsist on a novel where the central plot was already developed in another novel, ${ }^{39}$ the cover and internal design of a marketing material, ${ }^{40}$ the technical development of a creative idea via software, ${ }^{41}$ ceramic drawings with minimalist forms of antiquity to modern times, ${ }^{42}$ or the architectural form and static solutions of the cable bridge in Chalcis. ${ }^{43}$

Originality is more likely to be affirmed by reference to works of street art, in the form of murals, provided that they meet the 'author's own intellectual creation' requirement, understood as statistical uniqueness and creative height. Street messages and slogans could also meet this requirement depending on the way in which the short phrase is construed. Although some of these messages are merely descriptive of political dislikes (e.g. 'Down with the state' etc) and hence unlikely to attract copyright protection, others can qualify for protection to the extent that they are their

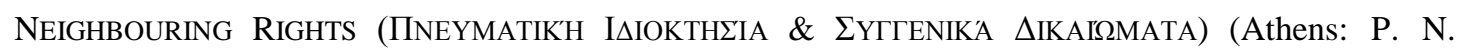
Sakkoulas YEAR, $2^{\text {nd }}$ ed.) at 27-31; LAMPROS KOTSIRIS, THE LAW OF INTELlECTUAL PROPERTY

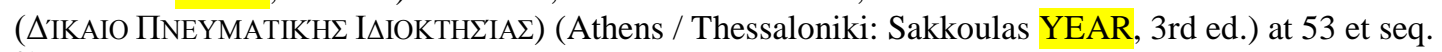

${ }^{31}$ Supreme Court (АП) 152/2005.

${ }^{32}$ Athens Court of Appeal (E $\left.\varphi \mathrm{A} \theta\right)$ 3214/2007.

${ }^{33}$ Supreme Court (AП) 20/2005.

${ }^{34}$ Athens Court of Appeal (E $\left.\varphi \mathrm{A} \theta\right)$ 80/2008.

${ }^{35}$ Ioannina Court of Appeal (E $\left.\varphi \mathrm{I} \omega \alpha v\right)$ 60/2008.

${ }^{36}$ Athens Court of Appeal (E $\left.\varphi A \theta\right)$ 2398/2008.

${ }^{37}$ Pireus Court of Appeal (E $\varphi$ Пв1 ) 281/2005.

${ }^{38}$ Court of First Instance of Athens (МПА) 2519/1997.

${ }^{39}$ Athens Court of Appeal (E $\left.\varphi A \theta\right)$ 358/2012.

${ }^{40}$ Athens Court of Appeal (E $\left.\varphi A \theta\right)$ 1036/2011.

${ }^{41}$ Athens Court of First Instance (МПА) 3163/2005.

${ }^{42}$ Athens Court of Appeal (E $\left.\varphi A \theta\right)$ 4091/2010.

${ }^{43}$ Supreme Court (AП) 1248/2003. 
author's own intellectual creation. ${ }^{44}$ It is doubtful whether tags can meet the originality requirement, as the condition on the threshold of creativity is unlikely to be met, even though some of them may be statistically unique. The same applies to 'throw ups' and graffiti letters more broadly.

\section{The merit of the work}

Same as in other continental EU Member States, copyright in Greece remains neutral as to the merit of the work. This is explicitly declared in Article 2(4) of Law 2121/93 which states that ' $[\mathrm{t}]$ he protection afforded under this Law shall apply regardless of the value of the work and its destination and regardless of the fact that the work is possibly protected under other provisions.' Theory accepts that there is no need for a positive assessment of the value of the work in legal, ethical or moral terms. According to this approach, copyright on an immoral or illegal work is protected irrespectively of the social dislike or legal punishment of the author. ${ }^{45}$ The position flows from the understanding that illegality or immorality covers human behaviour but does not encompass intellectual creations. ${ }^{46}$

Even though unauthorised street art, notably graffiti and tags, are very likely to be the result of illegal activity, they can remain copyright protected in case the subsistence requirements are met. Public authorities do indeed prosecute some forms of graffiti, particularly graffiti on public property, e.g. on trains or on public monuments. According to Articles 381, 382 and 383 of the Greek Criminal Code of 1951, there is a penalty of two years imprisonment for those that intentionally destroy or harm third-party property. In particular, Article 381 reads that if the damage to

\footnotetext{
44 A compilation of some Greek graffiti messages is available here (in Greek):

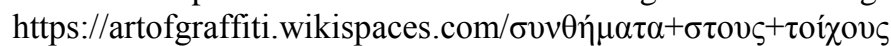

45 Georgios Koumantos, Intellectual Property (ПNeymatik'H I $\triangle$ IOKTHzia) (Athens: Ant. N. Sakkoulas 1995, $6^{\text {th }}$ ed.), at 110

${ }^{46}$ Ibid, KoumANTOS, 110 (and note 277, where he refers to this justification as flowing from the work of Fabiani, Opera, at 3)
} 
foreign property is made on an object of insignificant value or the harm caused due to the damage is minimal, the penalty is a fine or imprisonment for up to six months. Article 382(4) addresses special cases of damage, and it stipulates that whoever causes damage or harm to an archaeological or artistic or historical monument or to an object that is located in a public space is punished with imprisonment of at least one year if no heavier penalty is available through another legal provision. This set of legal provisions may apply to certain forms of unauthorised street art depending on their significance and irrespective of the fact that copyright may subsist in street art.

\section{Street art and scope of authorial entitlement}

\section{A. Authorship and ownership}

According to Article 6 of Law 2121/93, the initial rightholder of economic and moral rights attached to a work is the author of that work, with no need for any formality in order for the rights to subsist.

Article 7 defines a 'work of joint authorship' as any work that is the result of the direct collaboration of two or more authors, where the various contributions are not clearly distinguishable. In such cases, unless it is otherwise agreed, the rights are shared equally by the co-authors and the work cannot be subject to separate acts of exploitation from the various contributors. The NTUA graffiti, for instance, was likely a work of joint authorship, as it is impossible that a single person would be in a position to create a work of such a volume overnight and at the same time it is not easy to separate the various contributions.

According to Article 7(2), 'collective works' are those created through the independent contribution of several authors acting under the intellectual direction and coordination of one natural person. That natural person is the initial rightholder of the economic and moral rights attached to the collective work and every contributor is the 
initial rightholder of the economic and moral rights attached to their respective contributions, to the extent that each contribution is capable of separate exploitation. In the field of street art, a Municipality or public body commissioning the creation of a collective work cannot have a claim of being the initial rightholder, as Article 7(2) is considered to require an authorial input instead of a technical or financial contribution. If, however, the Municipality or public body appoint a director of that creative enterprise, the director will be considered the initial rightholder and each contributor will hold the rights on their respective contributions.

With regards to murals that are made subject to authorisation from the owner of the physical support, either a private party or a public body, these may qualify as employee-created works, if the conditions of Article 8 of Law 2121/93 are met. In case of an employment contract, the applicable presumption is that the author, i.e. the employee, is the first owner of copyright, including both economic and moral rights. Article 8 further specifies that,

' $[u]$ nless otherwise provided by contract, the only powers stemming from the economic rights that shall be transferred exclusively to the employer shall be those which are necessary to the fulfilment of the purpose of the contract'.

This is an internal limit of Article 8 on the basis of the proportionality principle. It is repeated emphatically in Article 15(2) of Law 2121/93, which indicates that

'[i]f the extent and the means of exploitation for which the transfer takes place or for which the exploitation or the exploitation licence is agreed are unspecified, it shall be deemed that the said acts refer to the extent and the means, which are necessary to the fulfilment of the purpose of the contract or licence'. 
It is worth stressing that the moral rights cannot be transferred (although they may be inherited).

Not all works created under authorisation, however, will be under an employment contract, and there may well be instances of commissioned work, which is more likely by reference to street art. In such cases, the initial copyright owner is the author of the work. This is so even where written or inferred terms in the contractual relationship specify the contrary; in those cases too, the initial rightholder is the author and the contractual term will determine when and to what extent the ownership transfer applies.

'Compound works' are defined in Article 7(3) as works that are composed of parts created separately. The authors of all of the parts are the initial co-rightholders of the rights attached to the compound work and each author is the exclusive initial rightholder of the rights of the part of the compound work which they have created, provided that that part is capable of separate exploitation. This form of authorship can be established in many cases of collaborative street art that may not be subject to central coordination but various street artists have attached their contribution on a preexisting work.

\section{B. Economic rights}

The economic rights of authors have been harmonised at EU level via the Information Society Directive, ${ }^{48}$ which was implemented in Greece in $2004 .{ }^{49}$ Article 13 of Law 2121/93 specifies that the economic rights of the authors include the power to permit

\footnotetext{
${ }^{48}$ Directive 2001/29/EC of the European Parliament and of the Council of 22 May 2001 on the harmonisation of certain aspects of copyright and related rights in the information society, OJ L 167, June 22, 2001.

${ }^{49}$ Law amending the Laws on Intellectual Property and Related Rights of 1976 to 2002, E.E..I(I), No. 3850, Apr. 30, 2004, 128(I)/2004.
} 
or prohibit the reproduction of the work by any means, such as mechanical, photochemical or electronic means; the translation of the work; the arrangement, adaptation or other alterations of the work; the distribution of the original or copies of the work via a transfer of ownership, a rental arrangement or public lending; the communication of the work to the public; the public performance of the work; the broadcasting or rebroadcasting of the work to the public by radio and television; the import of copies of the work produced abroad without the creator's consent or the import of copies from a country outside the European Economic Area when the right over such imports had been retained in contract by the author. Interestingly, the Law further defines in paragraph 2 of the same Article the concept of the 'public' as a constituent of most economic rights. This Article reads that

' $[t]$ he use, performance or presentation of the work shall be deemed to be "public" when the work thereby becomes accessible to a circle of persons wider than the narrow circle of the family and the immediate social circle of the author, regardless of whether the persons of this wider circle are at the same or different locations.'

Article 5 of Law 2121/93 expressly includes a resale right that is made available to authors of artistic works. According to this right, which is not transferrable between living persons, whenever an original work of fine art is resold at a public auction or by an art dealer or through the mediation of an art dealer, the author of the work and his heirs shall have the right to demand a percentage of five per cent of the sale price.

Although for authorised murals the graffiti artists can bring in proceedings for infringements of their economic rights, or to receive royalties under the resale right, it is rather unlikely that artists of unauthorised graffiti would uncover their identities 
and initiate claims of copyright infringement where their graffiti activities amount to a violation of one of the Criminal Code provisions. This is despite the fact that the work may be protected by copyright and the copyright theoretically enforceable in court.

\section{Freedom of panorama}

Greek copyright law does not make allowance for a broad freedom of panorama, namely a copyright exception that allows publishing pictures of artworks that are located in public places. This means that members of the public are not legally allowed to take and publish images of copyright protected street art, e.g. in the form of postcards or t-shirts, without infringing copyright. The practical significance is that copyright holders of protected street art are in principle entitled to bring in proceedings for infringement in cases of the unauthorised publication of photographs of their works. ${ }^{50}$

However, Article 26 of Law 2121/93 allows for a limited freedom of panorama exception to the mass media, regarding the use of visual images of works located in public places. In particular, the occasional reproduction and communication to the public by the mass media of visual images of architectural works, fine art works, photographs or applied art works, which are located permanently in a public place, is an act permitted by copyright and there is no need for the consent of the author or payment of a fee.

\section{Moral rights}

Moral rights are not regulated at the EU level but the protection available under Greek law is similar to what applies in other EU Member States. Protection is available both

\footnotetext{
${ }^{50}$ For a relevant discussion of mostly French cases see OlgA D. GAROUFALIA, ARTISTIC WORKS AND

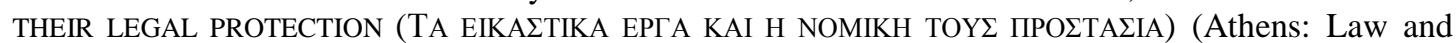
Economy, P. N. Sakkoulas 2001) at 208-209.
} 
under the general provisions of the Civil Code $^{51}$ and under copyright. The protection of moral rights under copyright is offered in Article 4 of Law 2121/93. These include the right to decide on the time, place and manner in which the work shall be published; the paternity right; the integrity right as the right to prohibit any distortion, mutilation or other modification of the work and any offence of the author due to the circumstances of the presentation of the work in public; the right to have access to the work, even when the economic right in the work has been transferred to a third party.

Even though the law outlines the specific activities that are protected through moral rights in Article 4, this is considered to be a merely indicative list. In this light, if the relationship of the author and the work is affected in another, not statutorily mentioned way (e.g. false claims regarding the creation of a work) this can also receive moral right protection. ${ }^{52}$ According to theory, moral rights are unlimited, absolute and inalienable. ${ }^{53}$ The nature of moral rights as unlimited and inalienable does not preclude the possibility of contractual restrictions on the rights. ${ }^{56}$

With regards to street art, two are the moral rights that are worth mentioning: these are the rights of paternity and integrity.

\section{Attribution}

Article 4(b) stipulates that authors shall have the power to demand that their position as authors of the work be acknowledged and, in particular, to the extent that it is possible, that their name is indicated on the copies of the work and noted whenever their work is used publicly, or, oppositely, if they so wish, that their work be

\footnotetext{
51 Articles 57 and 59 of the Greek Civil Code offer an all-inclusive, comprehensive right of personality of natural persons, the breach of which can lead to a viable claim of damages or other form of restitution.

52 Georgios Koumantos, Intellectual Property (Пneymatik'h I $\Delta$ IOKThzia) (Athens: Ant. N. Sakkoulas $1995,6^{\text {th }}$ ed.), at 233

53 Georgios Koumantos, Intellectual Property (Пneymatik'h I $\Delta$ IOKThzia) (Athens: Ant. N. Sakkoulas 1995, $6^{\text {th }}$ ed.), at 232

56 Georgios Koumantos, Intellectual Property (ПneymatiK'H I $\Delta$ IOKThzia) (Athens: Ant. N. Sakkoulas $1995,6^{\text {th }}$ ed.), at 234-235
} 
presented anonymously or under a pseudonym. Unlike other countries, such as the $\mathrm{UK}$, there is no assertion requirement. ${ }^{58}$

Theory divides the paternity right into two kinds of authorial protection: the substantive recognition of the fact that the rightholder is the author of the work and the power to be recognised as the author by projecting one's name over the work or in relation to the work. ${ }^{59}$ The result of these distinct powers is that no one else can claim that they are the authors of the work. The substantive power to be recognised as the author can be infringed through any written or oral, direct or indirect challenge, that may take place through words, actions or inaction. ${ }^{60}$ Because graffiti in Greece is illegal, artists often use pseudonyms and otherwise retain anonymity. There are no reported cases of breach of the paternity right of graffiti artists in Greece, as would be a book of photographs with no credits.

\section{Integrity}

Every modification of the work is likely to affect the personality of the author as imprinted in the work. Moral rights ensure that the author can prohibit any such modification or determine whether they wish to allow it. Before the introduction of the currently applicable Law 2121/93, Article 15 of Law 2387/1920 offered an integrity right covering any modification of the work and excluding third parties from going ahead with even minor changes on the work, which had to be authorised to be permitted. According to Article 4(c) of Law 2121/93, authors have the right to prohibit any distortion, mutilation or other modification of their work. The integrity right is manifested negatively, in the sense that the author can prohibit modifications they are not in accord with. The right can also be expressed positively in the sense of

\footnotetext{
${ }^{58}$ Cross reference to Enrico's chapter, XXX.

${ }^{59}$ Georgios Koumantos, Intellectual Property (Пneymatik'h I $\Delta$ IOKThzia) (Athens: Ant. N. Sakkoulas 1995, $6^{\text {th }}$ ed.), at 242

${ }^{60}$ The paternity right may be subject to contractual restrictions but such terms will only be valid to the extent that the central power of the right is not affected.
} 
the protection of the authors personality: in this light, authors should be able to make any modifications they deem necessary before the publication of their work or before every republication. ${ }^{62}$

The scope of the right depends on whether the work is uniquely materialised or not. In particular, for works of unique materialisation, such as works of art, including copyright protected street art, or architecture, any modification of the material support amounts to a modification of the work, and hence to an infringement of the integrity right. This is not the case by reference to works that come in multiple copies, such as lithographs, bronze sculptures or stencil street art, where a modification on one or more material supports does not amount to infringement, particularly so where the modified object remains in the private sphere of its owner. Infringement is deemed to take effect only once the modified object is communicated to the public. ${ }^{63}$

\section{a. Destruction of street art: a violation of the integrity right?}

The most intense, and difficult to resolve, conflict of the moral right to the integrity of the work with the ownership over the material support arises in cases of destruction of works of unique materialisation. Indeed, the destruction of a work is considered to be the ultimate form of derogatory treatment, even though destruction is not expressly mentioned as a direct or indirect form of derogatory treatment under Law 2121/93. Because the law remains silent, in cases of conflict between the intellectual property right on the work and the property right on the material support, e.g. the wall or other surface, on which the work is embodied, Courts have to balance the conflicting interests of both parties. In particular, they have to respond to the important question

Georgios Koumantos, Intellectual Property (ПNeymatik'H I $\triangle$ IOKThzia) (Athens: Ant. N. Sakkoulas $1995,6^{\text {th }}$ ed.), at 246-247

${ }^{63}$ Ibid, Koumantos, at 247; also see Olga D. Garoufalia, ARTistic WORKS AND THEIR LEGAL

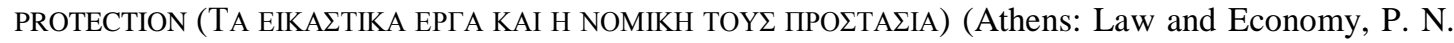
Sakkoulas 2001) at 177. 
over the extent of control that the owner of the physical embodiment of a work, especially by reference to works of unique materialisation. Is their power to destroy such a work absolute and, what is more, is it justifiable ${ }^{65}$

The general principles in understanding the balance between the conflicting forms of property-copyright and property on the material support-are that modifications on the work violate the integrity right, but in cases of destruction the property right prevails. Despite the absolute nature of the integrity right, the property right on the material support gives its owner the power to exercise control on the support, ${ }^{66}$ which could include the modification or even the destruction thereof. This is even more so in cases of imposed art, such as unauthorised graffiti art, where the destruction of the painting from the owner of the property is deemed acceptable and justified because the act of the graffiti artist is a violation of the owner's property right and a harm of foreign property according to the provisions of the Criminal Code. It is less clear whether the same position ought to apply in cases of authorised murals. In such cases, the balance between copyright and the property right ought to be subject to assessment. ${ }^{67}$

The rationale is that modification is more likely to have an impact on the honour and reputation of the author than destruction which leads to the elimination of the work altogether, because the latter form of derogatory treatment does not attribute to the author a work in an altered form: there is no work. As a matter of fact, destruction equals the permanent loss of the work, meaning that restoration is not a possibility, despite the possibility that the image of the artistic or architectural work

\footnotetext{
${ }^{65}$ See in this regard Athens Court of Appeal (E $\left.\varphi A \theta\right)$ 3325/2006.

${ }^{66}$ Georgios Koumantos, Intellectual Property (ПNeymatik' I IOIOKThzia) (Athens: Ant. N. Sakkoulas 1995, $6^{\text {th }}$ ed.), at XXX; OlgA D. GAROUfAliA, ARTISTIC WORKS AND THEIR LEGAL

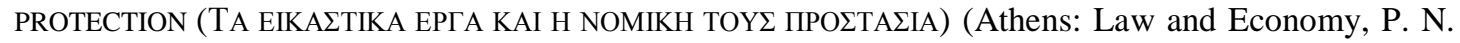
Sakkoulas 2001) at 173.

${ }^{67}$ Ibid, GAROUFALIA, at 174.
} 
may be preserved through a photograph or other visual representation. With regards to works of unique materialisation, the work and its tangible embodiment are fully dependent. This is exactly the case with street art, especially where the owner of the material support does not welcome the addition of an unauthorised, but copyright protected, graffiti and decides to erase it. Although it is unlikely that a graffiti artist that has created the work in breach of the provisions of the law on harm of foreign property (i.e. 381-383 of the Criminal Code) would bring proceedings for infringement of moral rights, the tension between the rights still exists and generates controversy.

\section{b. Destruction of street art and abusive exercise of the property right}

In both modification and destruction, the general prohibition of the abusive exercise of rights (available under Article 281 of the Civil Code) applies. According to Article 281 an abusive exercise of a right is one that exceeds the limits of good faith, established principles of morality or the social or financial purpose of the right. ${ }^{68}$

Artistic works incorporated in an immovable material support tend to become part of the property and a possible destruction is justified and not abusive to the extent that it is attributed to serious reasons, whereas for movable works of art, their destruction is more likely to be seen as abusive, especially if the option of reselling or abandoning the work is available. ${ }^{69}$ It is indeed less likely that the owner of a material support would destroy a work unless there were serious reasons, especially when the material support is immovable property. These could include reasons that have to do with public security or health or other public interests, for example, environmental

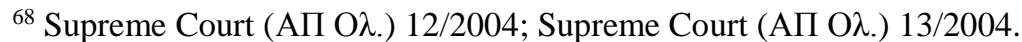

${ }^{69}$ Georgios Koumantos, Intellectual Property (ПNEymatik'H I $\triangle$ IOKTHzia) (Athens: Ant. N. Sakkoulas 1995, $6^{\text {th }}$ ed.), at 249; ANTHOUla PAPAdOPOUlOU, THE Author's Right IN THE PRESERVATION OF THE INTEGRITY OF HIS WORK (TO $\triangle$ IKA'IRMA $\triangle$ HMIOYPГOY ГIA $\triangle$ IATHPH $\Sigma H ~ T H \Sigma$

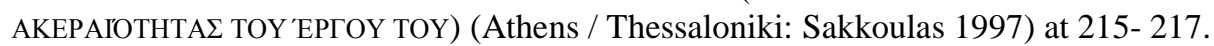


reasons or to carry out road works. ${ }^{70}$ It would be difficult to accept in such cases that the owner of a building cannot demolish a wall because a mural is painted on it, even more so when the artwork consists in an unauthorised graffiti work. It is, hence, acceptable to partially demolish the building or add an expansion within the limits of permissible use. ${ }^{71}$ However, intrusive modifications that have a merely aesthetic purpose are likely to infringe the integrity right. ${ }^{72}$ The same ought to apply to modifications that result from matters of merely personal taste of the author, e.g. instances that an author merely dislikes a copyright protected mural and decides to paint over it. Although theory seems to indicate that the property right prevails over the integrity right in cases of immovable property, ${ }^{73}$ especially when there are objective reasons justifying any modifications or alterations, various commentators propose the introduction of an obligation to notify the author before destroying the work, because this gives the author the opportunity to either buy the work, in whole or in part, or to repair the work, where this is possible, or to consent to the destruction of the work, if there is no other option. ${ }^{74}$

Regarding movable works, when the material support belongs to the State, such as a train coach, the possibility of transferring or abandoning the coach is often not readily available and hence the removal of the graffiti does not qualify as abusive.

\footnotetext{
${ }^{70}$ Ibid, PAPAdOPOUlou at 219, 220; Olga D. GAROUFAlia, ARTISTIC WORKS AND THEIR LEGAL

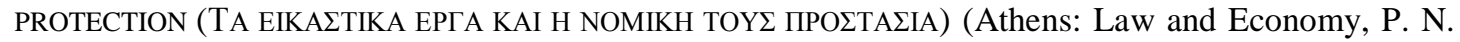
Sakkoulas 2001) at 163 et seq., 166, 168, 172-173.

71 Thessaloniki Court of First Instance $(\Pi \Pi \rho \Theta \varepsilon \sigma)$ 13300/2004; also in this regard OLGA D.

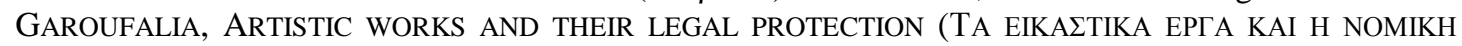

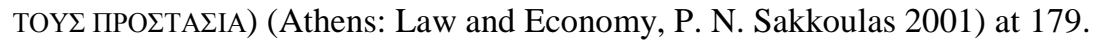

${ }^{72}$ LAMPROS KotSIRIS, THE LAW OF INTELLECTUAL PROPERTY ( $\triangle$ 'IKAIO ПNEYMATIK'H $\Sigma$ I $\triangle$ IOKTH $\Sigma$ IA $\Sigma$ ) (Athens / Thessaloniki: Sakkoulas YEAR, 3rd ed.) at 130-131.

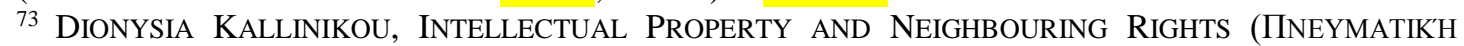

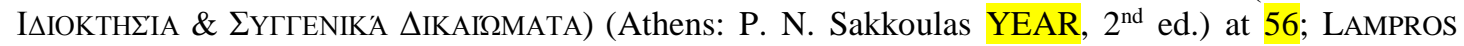

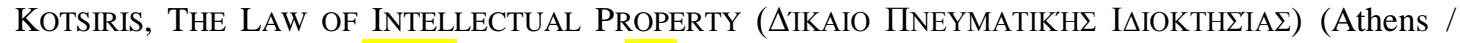
Thessaloniki: Sakkoulas YEAR, 3rd ed.) at 117

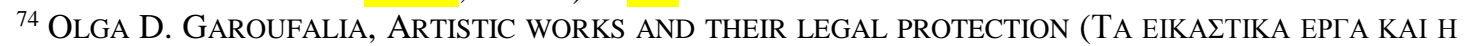

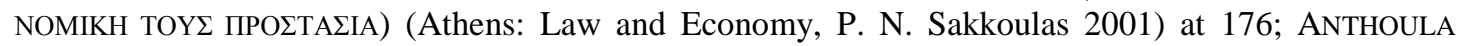
PAPAdOPOUlOU, THE AUTHOR'S RIGHT IN THE PRESERVATION OF THE INTEGRITY OF HIS WORK (TO

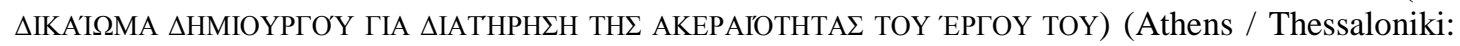
Sakkoulas 1997) at 217.
} 
This is not the case however when alternative options for the removal of a work are available. For instance, the Court of Appeal of Ioannina found that the non-expert removal of a sculpture that was permanently located in a public space was an infringement of the integrity right of its author because the public workers removing it had not respected the individuality and uniqueness of the work and the personality of its author. This was mostly so because they had not taken any measures to protect the work despite the author's notices about the difficulties of removing the work and his willingness to take care of the removal free of charge. ${ }^{75}$

As a general rule, the destruction of a work of art would only be justifiable to the extent that the owner of the material support does not exceed the social purpose of the right, including the public interest in the preservation of cultural and intellectual goods, and the authorial entitlement in the preservation of intellectual creations. Where the modification or destruction is deemed to be abusive on the basis of Article 281 of the Civil Code, a claim on damages can be viable by virtue of Article 914 of the Civil Code. One relevant parameter in assessing whether a modification or destruction has been abusive has to do with the quality and artistic value of the work. There is an established public interest to preserve works that are deemed to be of a special artistic value, and this could be said to be the case for highly original street art. Destruction of such works does not align with their social purpose.

\section{c. De-contextualisation of street art}

An obligation to pay damages on the basis of Article 914 of the Civil Code can also arise when the owner of a work of unique materialisation moves the work from one place to another or removes it from a particular location in a way that qualifies as a destruction. The environment in which the work is located and the way in which the

\footnotetext{
${ }^{75}$ Ioannina Court of Appeal (E $\left.\varphi \mathrm{I} \omega \alpha v\right)$ 60/2008.
} 
work becomes part of it may also be subject to protection in that de-contextualisation could amount to infringement of the integrity right.

Greek copyright goes beyond the substantive minima of the Berne Convention as it provides protection against violations of the integrity of the work and it also entitles rightholders to

'have access to [the] work, even when the economic right in the work or the physical entity of the work belongs to another person: in those latter cases, the access shall be effected with minimum possible nuisance to the rightholder' ${ }^{76}$

This is particularly so when the move or removal concerns a work of art that is destined for public view by being placed either in a public location or in a private space that is accessible to everyone in a way that is meant to aesthetically upgrade the place or to serve a symbolic or memorial function. In such cases, the public exhibition of the work equals its incorporation in a particular environment and there is a public perception that the work is linked to a particular location. Equally, placing the work in an environment that is clearly not appropriate may amount to infringement of the integrity right and of the right to protect the work and the impression it creates. An example is the removal of a sculpture from a central square, where the work was originally created and destined for, to a less central location. This was found to amount to an infringement of the integrity right. ${ }^{77}$ The removal and repositioning of an artistic work of street art in an inappropriate location could be seen as derogatory of both moral rights according to Greek law. That could be the case of removing a mural to exhibit in a museum, a gallery or other indoor environment. Another possibility could include a work created in an urban environment that was subject to

\footnotetext{
${ }^{76}$ Law 2121/93, Article 4(1)(d) (1993).

${ }^{77}$ Athens Court of First Instance (ПП $\omega \tau$ А $\left.\theta\right)$ 1447/1962.
} 
subsequent gentrification, with the author no longer considering this new environment appropriate for their work.

\section{The moral rights of the State}

A particularly interesting aspect of Greek copyright is that there is a moral right offered to the Greek State. According to Article 29(2) of Law 2121/93, after the expiry of the term of copyright protection, i.e. life of the author plus 70 years post mortem auctoris, the State (represented by the Minister of Culture) may exercise the rights on the acknowledgement of the author's paternity and the rights on the protection of the integrity of the work stemming from the moral right pursuant to Articles 4(1)(b) and 4(1)(c). The provision can interestingly apply to works for which the copyright has expired, even ancient monuments and artefacts. ${ }^{78}$ This form of protection covers the integrity of cultural heritage and it has the result that moral rights protection in Greece is perpetual, even though it may change beneficiaries after the lapse of the authorial term of protection. The rationale is that in some instances it may be impossible to find the authors or the heirs of a work but certain works ought to retain their integrity and proper authorial attribution intact for public policy reasons. In such cases, law entrusts society via the State, and in particular the Minister of Culture, to enforce the moral rights. ${ }^{79}$ This strengthens the position of the State in cases of graffiti on publicly-owned architectural works or religious establishments in that the infringement of the integrity right can be claimed irrespectively of the fact that copyright has expired or has never been asserted.

Whereas the obvious violation seems to be the infringement of the integrity right of the graffiti artist(s) when the owner of the material support erases the street

\footnotetext{
${ }^{78}$ Georgios Koumantos, Intellectual Property (Пneymatik'h I $\Delta$ IOKThzia) (Athens: Ant. N. Sakkoulas 1995, $6^{\text {th }}$ ed.), at 236.

${ }^{79}$ At a broader level, this provision is particularly noteworthy by reference to the regulation of orphan works.
} 
art or applies other forms of treatment on it, a parallel form of infringement of the integrity right may also be established under Greek copyright. This time the beneficiary is the State itself when unauthorised street art has been painted on buildings that are protected as architectural works or other monuments that may have been subject to copyright protection at some point in time. An infringement of the integrity right of the State due to the derogatory treatment of public property could also be established in such cases. This is less likely so, when the State or other public body has given their authorisation to graffiti artists or have commissioned the work, and in such a case infringement may only arise because the quality or content of the artwork is derogatory or offensive.

\section{Street art and public opinion}

Street art, and graffiti and tags in particular, are often regarded to be a form of visual pollution, ${ }^{80}$ and for this reason their destruction or removal from a particular location is often regarded as desirable by members of the public. Even where this would amount to infringement of moral rights, it is unlikely that graffiti artists would put themselves forward and claim breach of copyright, as this would necessitate revealing their identities. Unauthorised graffiti, however, as we have seen earlier, remains illegal and punishable under the Criminal Code. Although it is not clear how citizens would regard graffiti-is it art or vandalism - and opinions vary, ${ }^{81}$ graffiti is perceived as a sign of social and environmental degradation. The more this becomes the leading view, the more the correlation with fear of crime is established. ${ }^{82} \mathrm{~A}$

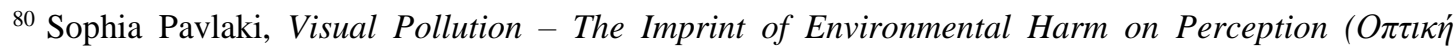

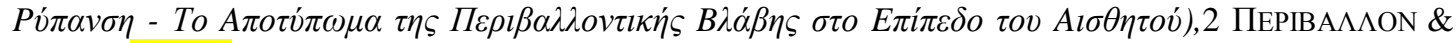
$\triangle$ IKAIO, (2016).

${ }^{81}$ Eutychia Georgiadi, Forms of Environmental Degradation, “Antisocialities" and Sentiment of

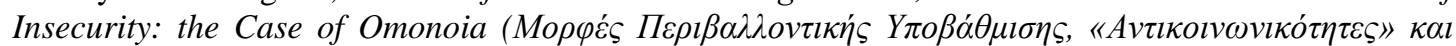

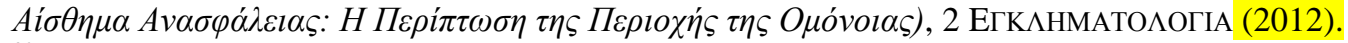

${ }^{82}$ Christina Zarafonitou, Elements of environmental degradation and the fear of crime: the case of

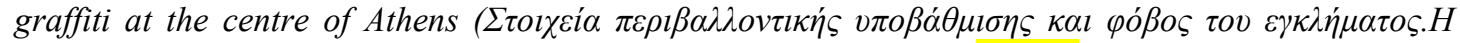

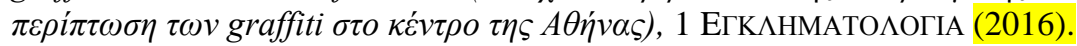


popular online newspaper, Lifo, carried out two polls in order to gather readers' view on graffiti. The first one was asking readers whether they agree with graffiti interventions such as the one at NTUA and a $40.77 \%$ voted against it and about $36.52 \%$ said they agree with such interventions under certain conditions only. ${ }^{83}$ The second poll was on whether graffiti and tags should remain in Athens and it revealed that $51 \%$ voted no, $27 \%$ opined that it should be graffiti only to remain (referred to as an encompassing term referring to street art and excluding tags) and no one was in favour of the maintenance of tags. ${ }^{84}$

This is just one of the instances revealing that there is a negative public opinion about tagging works and this is notably due to the visual pollution that is caused by the unauthorised making of tags, bubble letters and other, often less artistic forms of, graffiti. Especially in light of the economic crisis of recent years, paying public money to erase offensive graffiti on publicly owned buildings or monuments, or having individual citizens having to pay themselves to paint their own walls because graffiti artists remain notoriously anonymous, accelerates negativity in the public perception on graffiti works and raises questions on stronger enforcement against illegal graffiti art.

In August 2013, the Municipality of Athens launched an initiative on the cleaning of buildings located in historical roads of Athens in collaboration with organised groups of citizens that are discontent with the situation on the Athenian

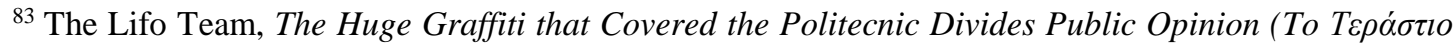
Гкра́ http://www.lifo.gr/now/culture/62078.

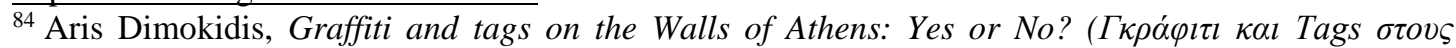

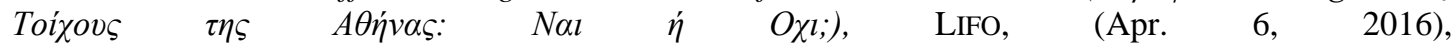
http://www.lifo.gr/articles/mikropragmata/96245 (where a poll about public opinion on whether graffiti and tags should remain in Athens revealed that $51 \%$ voted no, $27 \%$ opined that it should be graffiti only to remain and $0 \%$ was in favour of the maintenance of tags)
} 
urban environment. ${ }^{85}$ The biggest problem they are facing are tagging and slogans on walls of neoclassical buildings and stores but less so the creative street art-even unauthorised graffiti murals - that they aim to preserve. The response of graffiti artists was to write slogans on the cleaned walls, such as a message to the mayor of

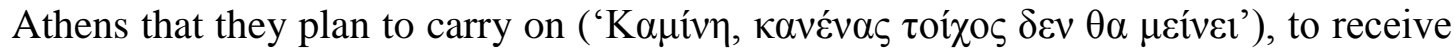
a dedicated response from the Mayor who ensured that that message too would be erased within one hour.

A more recent initiative involves the active, coordinated and voluntary contribution of citizens themselves who aim to clean Athens, and the rest of Greece, from tagging. The project, which is called 'Let's do it Greece: Athens UnTag', ${ }^{86}$ urges citizens throughout Greece to assist in removing tags from central areas of Athens and elsewhere, using special paint that makes subsequent tag removal easier. It is over 150.000 citizens that are participating in this project, which started on April 29, 2018 in central Athens. ${ }^{87}$

It is noteworthy that the State is making effort into turning the public perception on street art into a positive one, even though well-organised initiatives to eliminate tagging and unlicensed graffiti are also set in place. The Ministry of Environment launched in 2014 a pilot programme on Visual Art Interventions on Public Space: Paintings on Blind Sides of Buildings in Athens ('TÉ $\chi v \eta \kappa \alpha$ $\delta \eta \mu o ́ \sigma t o \varsigma$

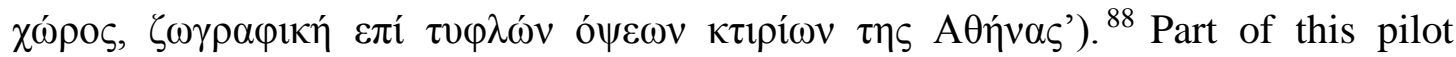

\footnotetext{
${ }^{85}$ The Municipality has also issued a brochure to give guidance on how to erase graffiti and tags:

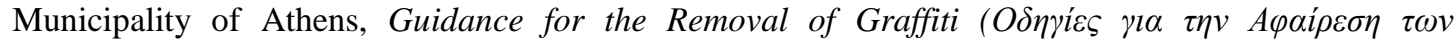
$\Gamma \kappa \rho \alpha \varphi i \tau \imath)$, http://www.naftemporiki.gr/cmsutils/downloadpdf.aspx?id=1083247.

${ }^{86}$ Filio Ragkou, Athens UnTag wants to clean Athens from Tagging (H $\delta \rho \alpha \dot{\sigma} \eta$ 'Athens UnTag' $\theta \dot{\lambda} \lambda \varepsilon l v \alpha$

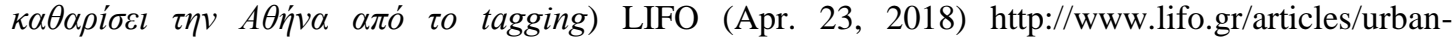
art_articles/189375/i-drasi-athens-untag-thelei-na-katharisei-tin-athina-apo-to-tagging

${ }^{87}$ Lifo Team, Athens UnTag - The Volunteers that Cleaned the Centre of Athens from Tags Today

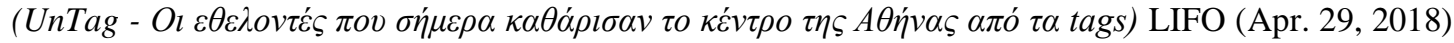
http://www.lifo.gr/now/greece/190779/athens-untag-oi-ethelontes-poy-simera-katharisan-to-kentro-tisathinas-apo-ta-tags\#comment ${ }^{88} \mathrm{http}: / /$ www.dasta.asfa.gr/files4users/files/STREET_ART_WEB.pdf;
} 
programme is one of the most famous, and possibly iconic, scenes of Greek street art, featuring on an empty wall of the ten-store hotel 'Vienna', located in the heart of the city, very close to Omonoia Square. The title of the piece is 'Praying for us', even though it is more commonly known as the 'reverse prayer' (Figure 2). It pays homage to Albrecht Dürer's 'Praying Hands', but here the prayer does not lean upwards but towards the earth, as if it is God himself praying. The artistic project that was conceived by a student of the School of Fine Arts, Pavlos Tsakonas, and realised by a number of painters, stands as the affirmation that street art can give memorial dimensions to art and transform public perception of graffiti art as visual pollution.

\section{[INSERT FIGURE 2 HERE]}

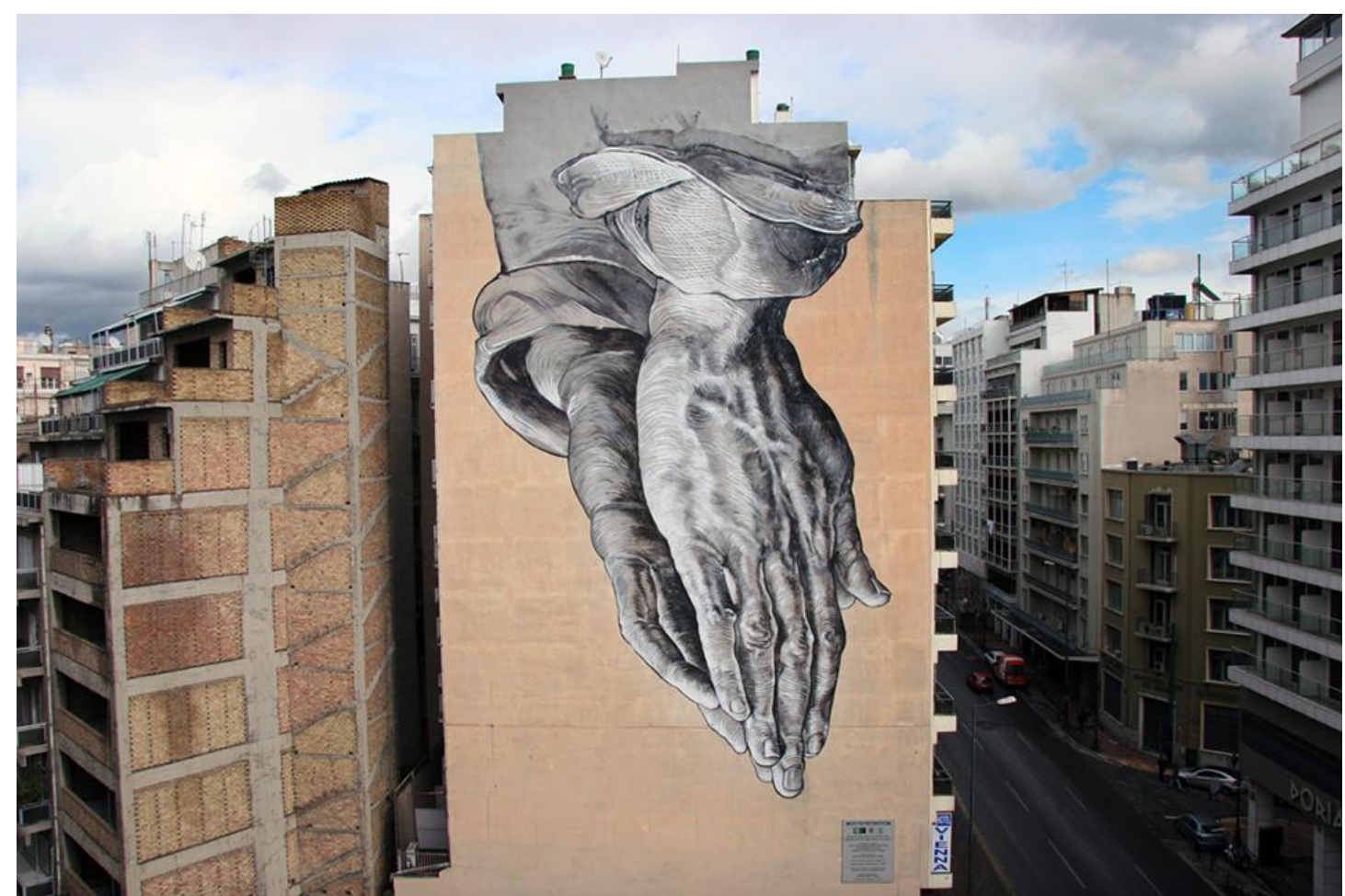

Figure 2: 'Praying for us'. Image taken from: https://www.pinterest.co.uk/pin/212372938648272439/

For a comment, see Dimitris Ginosatis, Practices of Seeing -- A Brief Commentary on Artistic

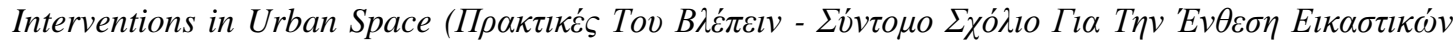

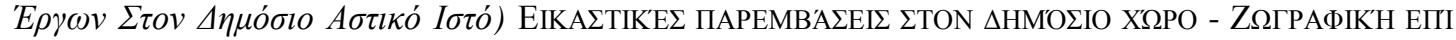

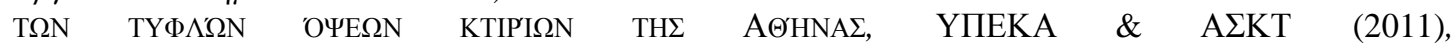
https://papers.ssrn.com/sol3/papers.cfm?abstract_id=2721369. 


\section{Conclusion}

Street art and graffiti in Greece have spurred in recent years, changing fundamentally the urban landscape. Although a social nuisance and the by-product of illegal activity according to the Greek Criminal Code when taking place without authorisation, certain kinds of this artistic form can receive copyright protection. This raises questions of economic exploitation under copyright and-more importantly-likely infringements of the integrity right where the owner of the material support decides to erase the graffiti. With regards to the conflict between copyright on the work and personal property on the tangible embodiment, tension tends to be more frequently balanced in favour of the owner of the material support, on condition that this does not amount to the abusive exercise of the property right. This is even more so by reference to publicly owned buildings and monuments, where criminal law penalties for unauthorised graffiti are heavier. In conflicts between copyright and property rights regarding the destruction of graffiti art, the unauthorised and illegal nature of the activity will more likely shift the balance towards the owner of the material support.

About two or three hundred years ago, graffiti took the form of inscriptions recording a visit to ancient Greek monuments. Generations of European tourists left such marks on ancient temples and columns in Greece around the 19th century. Such inscriptions, which are visible in most archaeological sites, are possibly more offensive than modern graffiti in that they harmed monuments of important cultural value and they can also not be undone. Perhaps the most famous is the one bearing the deeply engraved name of a young English tourist who carved his name into the ancient Temple of Poseidon in Cape Sounion. This was no other than the Romantic 
poet Lord Byron who fought along the Greeks on the war of liberation against the Ottoman Empire. Although there is no direct evidence that the inscription was made by Byron himself, Byron writes in his poem Isles of Greece:

Place me on Sunium's marbled steep,

Where nothing, save the waves and I,

May hear our mutual murmurs sweep. ${ }^{89}$

Byron's engraved signature has now become a sightseeing site in its own right and about two centuries after its making archaeologists view this handiwork as holding a special historical value- even though modern tags marking territory do not seem to be as welcome.

Although this could hardly be comparable to most of the unauthorised tagging and graffiti, street art — especially when carried out with some insight and planninghas a true potential of improving our public experience of the urban environment.

${ }^{89}$ George Gordon Byron, The Isles of Greece, in ARTHUR QUILLER-COUCH (ED.) THE OXFORD BOOK OF ENGLISH VERSE: 1250-1900 (Oxford, Oxford University Press 1919) 601, verses 91-93, http://www.bartleby.com/101/601.html. 